\title{
IDENTIFICATION AND ECOLOGY OF WASPS (APOCRITA: HYMENOPTERA) OF DHAKA CITY
}

\author{
Tangin Akter*, Jannat Ara Jharna, Shanjida Sultana, \\ Soheli Akhter and Shefali Begum \\ Department of Zoology, University of Dhaka, Dhaka-1000, Bangladesh
}

\begin{abstract}
During the study period a total 351 wasp was collected from three different areas of Dhaka city viz Curzon Hall, Ramna Park and Sher-e-Bangla Agricultural University from October 2017 to May 2018. Among them 14 species belonging to four families-Ampulicidae, Sphecidae, Vespidae and Scoliidae were identified. The species were Ampulex compressa, Chalybion bengalense, Scoliasp., Laeviscolia frontalis, Delta esuriens, Rhynchium quinque cintum, Antodynerus flavescens, Parapolybiavaria sp., Ropalidia marginata, Polistes olivaceus, Polistes watti, Polistes stigma, Vespa tropica, and Vespa affinis. Standard taxonomic keys and sharp perception of outside morphology like head, wing venation, antennal sort, physical coloration etc. of the wasps were examined to identify them. Maximum of the distinguished species were beneath the family vespidae $(72 \%)$. In the present study, it was observed that the maximum number of wasps were collected in May $(29.63 \%)$. The richness of wasp species was more plenteousin Curzon Hall area $(47.58 \%)$ than the Sher-e-Bangla Agricultural University area $(40.17 \%)$ and was less abundant in Ramna park $(12.25 \%)$. The main reason for finding more richness of wasp species in Curzon Hall area was the presence of various types of hedging plants than other two areas as the wasps were found to prefer hedging plants for foraging. It was also observed that Polistes olivaceus $(21.93 \%)$ was the most abundant and Chalybion bengalense was $(0.85 \%)$ the least abundant species in the study areas.
\end{abstract}

Key words: Hymenoptera, Wasp species, Abundance, Host plant. Dhaka city

\section{INTRODUCTION}

Hymenoptera is one among the four expansive orders of insects (Goulet and Huber 1993). They are familiar to general people as: wasps, bees, ants, bumblebees, sawflies, parasitic wasps (Rasplus et al. 2010). The taxa of Hymenoptera include two suborder named Symphyta and Apocrita. New genera and species are frequently encountered and total 8423 extant genera with an additional 685 extinct genera were described by Alexandre et al. (2013). Apocrita incorporate the commonplace ants, bees, and wasps, as well as minor wasp-like parasites. Hymenopterans are a naturally assorted gather of insects, extending in measure from the miniature to large and from slender to robust. They are found around the world, but are more copious and assorted in tropical and temperate regions (Grzimek et al. 2003). Steffan-Dewenter (2003) predicted that species richness and abundance of plants, bees, wasps, and natural enemies increase with

*Author for corresponding: <aktert1@yahoo.com>

C2019 Zoological Society of Bangladesh DOI: https://doi.org/10.3329/bjz.v48i1.47874 
habitat area. A number of them are phytophagous, others are entomophagous, or both (Jennings and Austin 1996). Hymenopterans play a fundamental role in all terrestrial ecosystems (Grimaldi and Engel 2005). They can also act as pests and can be dangerous. Apocrita are specializes most obviously by the incredibly narrowed connection between abdominal segments 1 and 2, which gives greater flexibility. The family Vespidae serves as a biological control agent as they feed their larvae on aphids and caterpillars. They are important pollinators of fruit and vegetable crops. Wasps also play as minor pollinators (Naumann, 1991).

The present global knowledge on the wasp fauna is satisfactory but the exact data for countries like Bangladesh is still lacking. There is no record of area based taxonomic works in Dhaka city on wasps. So, the objectives of the research work were to study the species richness of the collected wasps in the study areas and to observe the wasp activities and know about the plants associated with them within the selected areas of Dhaka city, Bangladesh.

\section{MATERIAL AND METHODS}

The wasps were collected from three neighborhood dzones of Dhaka cityCurzon Hall Campus, Ramna park and Sher-e-Bangla Agricultural University Campus amid daytime (usually between 8 a.m. to 12 p.m.). They were collected two times from each chosen sites each month from October, 2017 to May, 2018, captured by basic hand net by sweeping. Collected wasps were brought to the Entomological laboratory of the Department of Zoology, University of Dhaka and sorted out. At that point they stuck and put to begin with three to four days beneath delicate day light for 20-25minutes to evacuate overabundance dampness and after that preserved in laboratory. Some naphthalene tablets were kept inside the box for their protection.

Specific characteristics were observed to identify the collected specimens. The specimens were identified by observing their body parts like color pattern, wing venation and shape, antennae, head etc. A number of literatures were followed to identify the wasps which include Goulet and Huber (1993), Borror et al. (1971).

\section{RESULTS AND DISCUSSION}

Keen observations of specific body parts of the wasps like physical wing venation, antennae, head etc. were made to identify the wasps (Fig. 1). During the study period 14 wasp species were identified belonging four familiesAmpulicidae, Sphecidae, Scoliidae and Vespidae. Among 14 species $72 \%$ belong to vespidae family (Fig. 2). The same study was conducted by Nidup et al. (2017) who documented eighteen species of scoliid wasps from Bhutan. Again, Agul (2016)found 117 specimens of hairy wasps belonging to the family Scoliidae 
Table 1: Distribution of different species of wasps collected from different locations of Dhaka city

\begin{tabular}{lcccc}
\hline \multicolumn{1}{c}{ Species } & Curzon Hall & Ramna Park & Shere-e-Bangla & Total \\
\hline A. compressa & 7 & 1 & 0 & $8(2.28 \%)$ \\
C. bengalense & 1 & 0 & 2 & $3(0.86 \%)$ \\
Scoliasp. & 18 & 0 & 4 & $22(6.28 \%)$ \\
L. frontalis & 0 & 0 & 7 & $7(1.99)$ \\
D. esuriens & 2 & 0 & 6 & $8(2.28 \%)$ \\
R. quinquecintum & 10 & 6 & 0 & $16(4.56 \%)$ \\
A. flavescens & 7 & 0 & 0 & $7(1.99 \%)$ \\
P. varia & 5 & 0 & 0 & $5(1.42 \%)$ \\
R. marginata & 43 & 0 & 26 & $69(19.66 \%)$ \\
P. olivaceus & 20 & 12 & 45 & $77(21.93 \%)$ \\
P. watti & 18 & 4 & 39 & $61(17.38 \%)$ \\
P. stigma & 9 & 0 & 0 & $9(2.56 \%)$ \\
V. tropica & 6 & 0 & 0 & $6(1.71 \%)$ \\
V. affinis & 21 & 20 & 12 & $53(15.1 \%)$ \\
$\quad$ Total & $167(47.58 \%)$ & $43(12.25 \%)$ & $141(40.17 \%)$ & 351 \\
\hline
\end{tabular}

Table 2: List of plants from which wasps were collected from October 2017-May 2018

\begin{tabular}{|c|c|c|c|c|c|c|c|c|c|c|c|c|c|c|c|c|c|c|c|}
\hline Family & Species & $\mathbf{A}$ & B & $\mathbf{C}$ & D & $\mathbf{E}$ & $\mathbf{F}$ & $\mathbf{G}$ & $\mathbf{H}$ & I & $\mathbf{J}$ & $\mathbf{K}$ & $\mathbf{L}$ & $\mathbf{M}$ & $\mathbf{N}$ & $\mathbf{O}$ & $\mathbf{P}$ & $\mathbf{Q}$ & $\mathbf{R}$ \\
\hline \multirow{9}{*}{ vespidae } & P. olivaceus & & + & & & + & & & & + & + & + & & & & & + & + & \\
\hline & P. swatti & + & + & & & + & & & & + & + & & & & + & & + & & \\
\hline & P. stigma & & & & + & & & & & & + & & & & & & & + & \\
\hline & V. affinis & + & & + & & & & & & & + & & & & + & & & + & \\
\hline & V. tropica & & & & & & + & & & & + & & & & & & & & \\
\hline & R. marginata & + & & & & & & & & & + & + & & & + & & & + & + \\
\hline & R.quinquecintum & & + & & & & & & + & & + & & & & & & & & \\
\hline & D. esuriens & & & & & & & & + & + & + & & & & + & & & + & \\
\hline & P.varia & & & & & & & & & & + & & & & & & + & & \\
\hline \multirow{5}{*}{$\begin{array}{c}\text { Scolidae } \\
\text { Ampulidae }\end{array}$} & A.flavescens & & & & & & & & & & + & & & + & & & & & \\
\hline & Scoliasp. & & & & & & + & + & & & + & & + & & + & + & & & \\
\hline & L. frontalis & + & & + & & & & & & & + & & & & & & & & \\
\hline & C. bengalense & & & + & & & & & & & + & & & & & & & & \\
\hline & A. compressa & + & & + & & & + & & & & + & & & & & & & & \\
\hline
\end{tabular}

Here, $\mathrm{A}=$ Alternanthera philoxeroides (Malonchoshak, green color), $\mathrm{B}=$ Abelmoschus esculentus (Okra, white color), $\mathrm{C}=$ Averrhoa carambola (star fruit, violet color), $\mathrm{D}=$ Buxus microphylla japonica (Japanese box, green color), $\mathrm{E}=$ Brassica nigra (Black mustard, yellow color), $\mathrm{F}=$ Cosmos sulphureus (Cosmos, yellow color), $\mathrm{G}=$ Cynodon dactylon (Durba, green color), $\mathrm{H}=$ Caesalpinia pulcherrima (peacock flower, red color), $\mathrm{I}=$ Corchorus capsularis (White jute), $\mathrm{J}=$ Hedging plants (green color), $\mathrm{K}=$ Lantana camara (Common lantana, purple color), $\mathrm{L}=$ Leucanthemum vulgare (oxeye daisy, white color), $\mathrm{M}=$ Mesua ferrea (Nageshar, white color), $\mathrm{N}=$ Syzium samarangense (Jamrul, white color), $\mathrm{O}=$ Solanum melongena (Brinjal, white color), $\mathrm{P}=$ Vigna radiate (Green gram, yellow color), $\mathrm{Q}=$ Zanthoxylum fagara (Prickly-ash, yellow color), $\mathrm{R}=$ Duranta rapens (Golden duranto, yellow color). 
which were collected from different regions of Iraq, and Wenzel (1998)described 31 genera of Vespidae. Akteret al. (2019) described 11 bee species (Hymenoptera: Apocrita) recorded in three different localities of Dhaka city. Three species of Polistes was identified P. olivaceus, P. watti, and P. stigma.

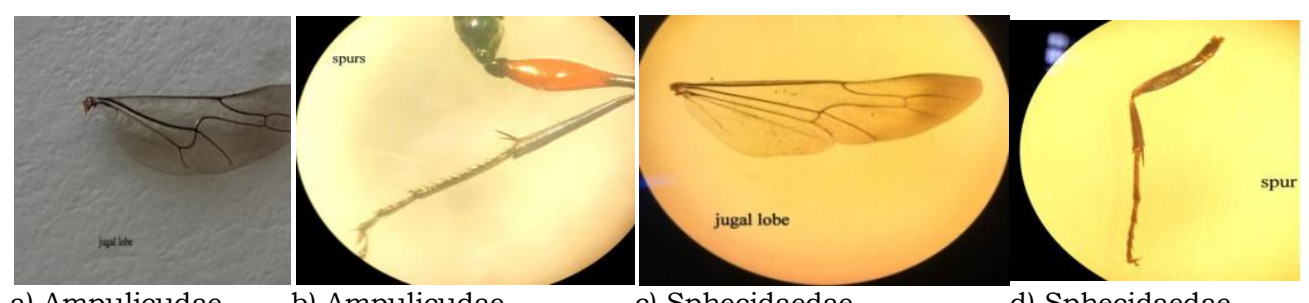

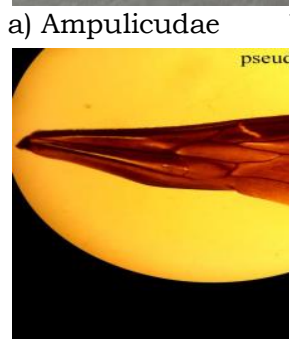

e) Scolidae

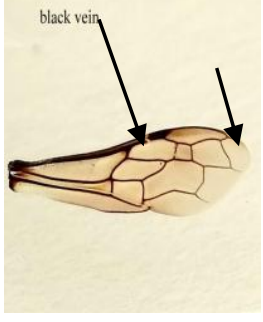

i)ForewingA.compressa

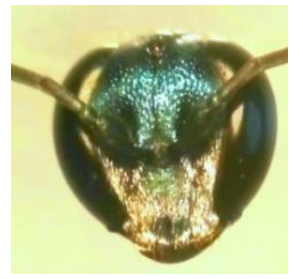

m) Head of Chalybion bengalense b) Ampulicudae

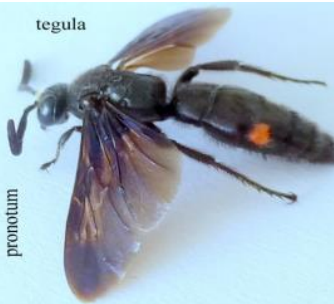

f) Scolidae

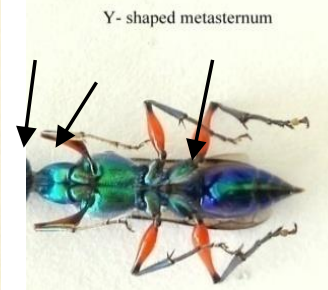

j) Body, A. compressa

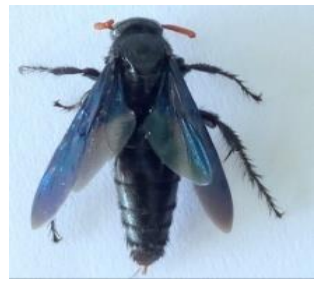

n) Scolia $s p$. c) Sphecidaedae

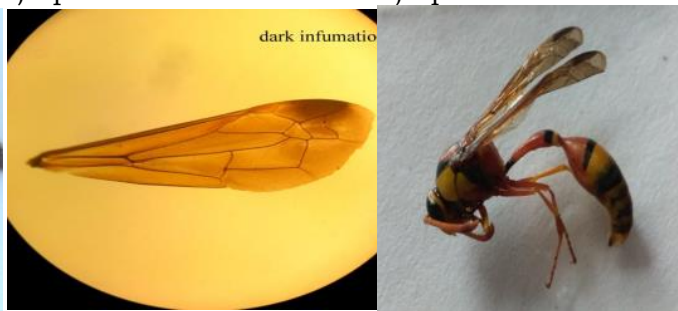

g) Vespidae

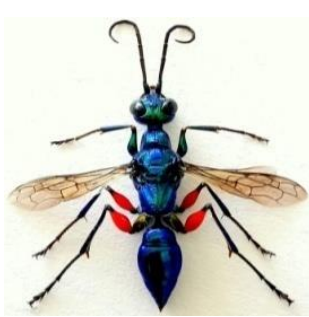

k)A. compressa

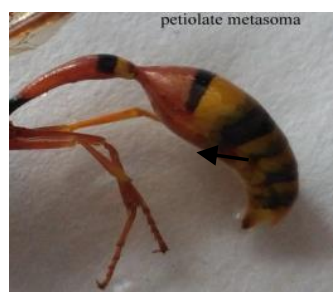

o)Abdomen Delta
h)Vespidae

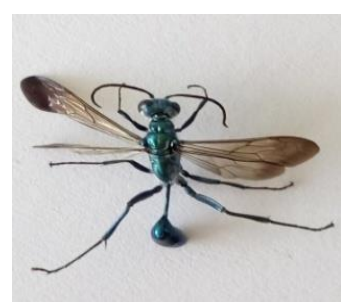

1) Chalybion

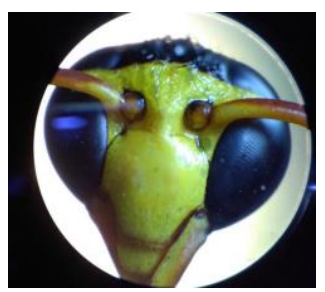

p) Head of Delta 

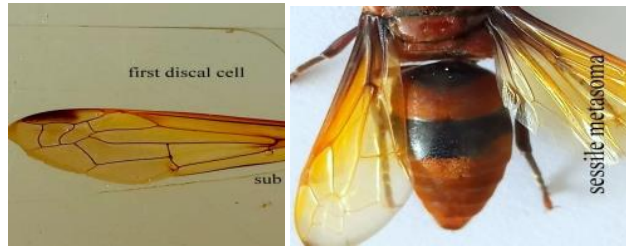

r) Body, Rhynchium

q) Fore wing, D.esuriens
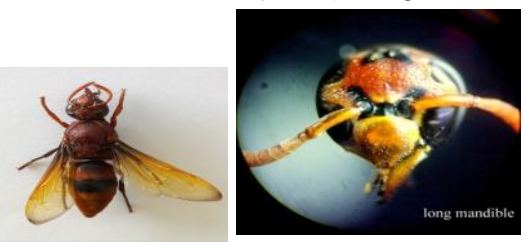

u) R. quinquecintum

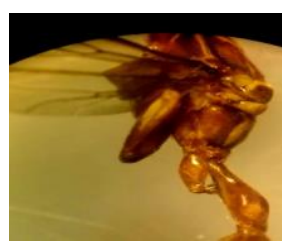

v) Head, Antodynerus

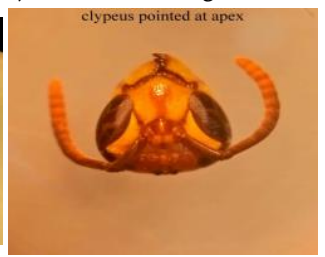

y) Body, Parapoly-bia
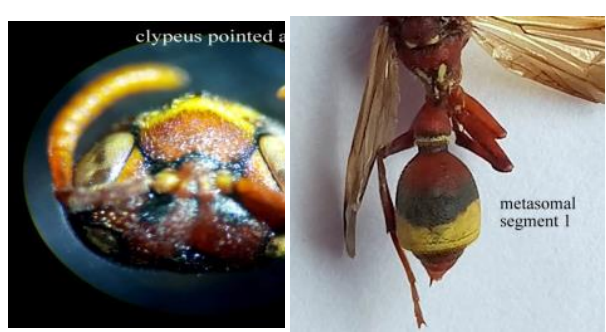

d') Body, R. marginata

c') Head of Rhopalidia
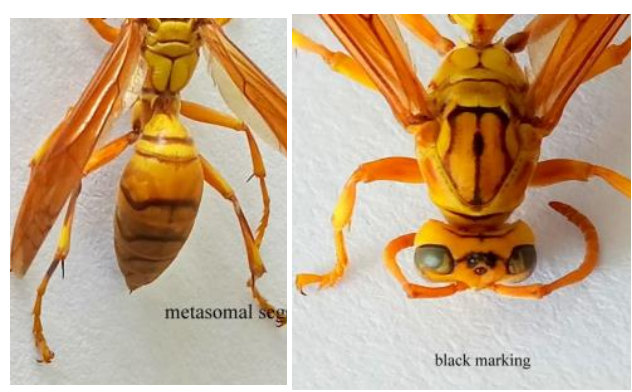

g') Body of Polistes

h') Body, P.olivaceus

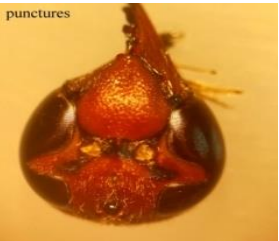

S) Head, Rhynchium

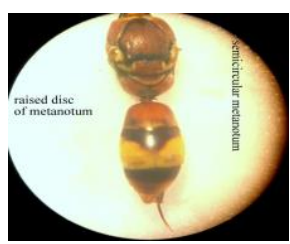

w) Body A. flavescens

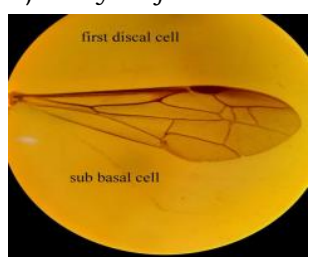

A') Fore wing, P. varia

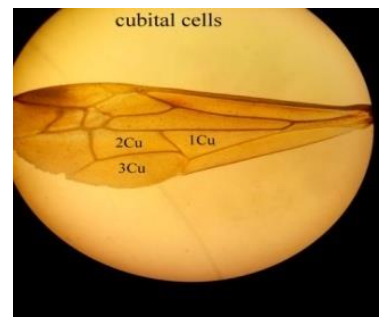

e') Fore wing R. marginata

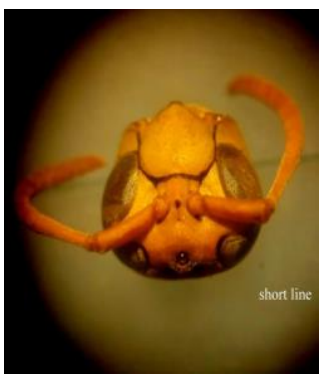

i')Head, P.olivaceus

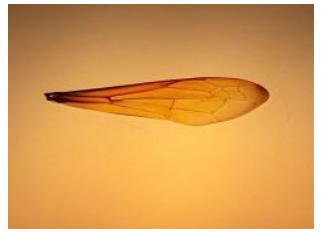

t) Fore wing, $R$. quinquecintum

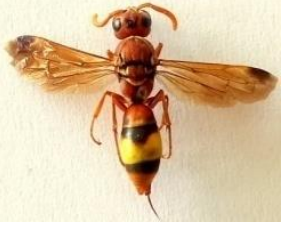

x) A. flavescens

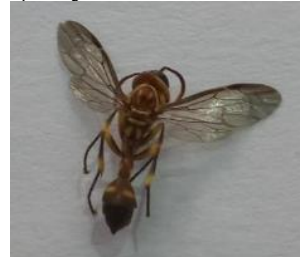

b') P. varia

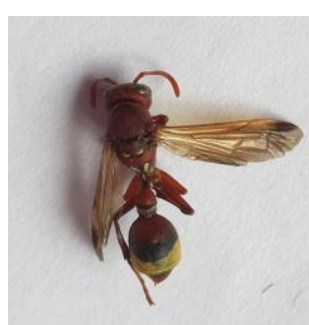

f) R. marginata

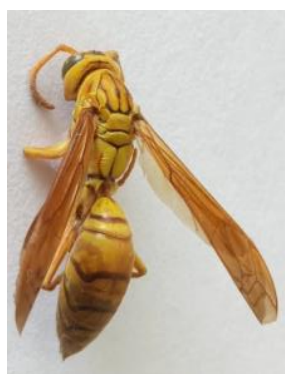

j') P.olivaceus 


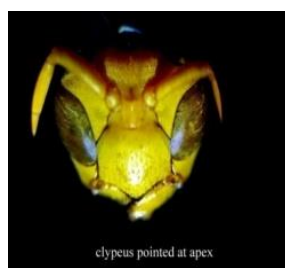

k') P.watti

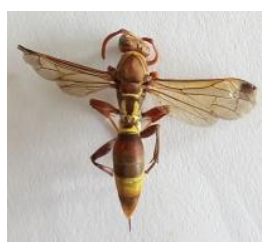

o')P.stigma

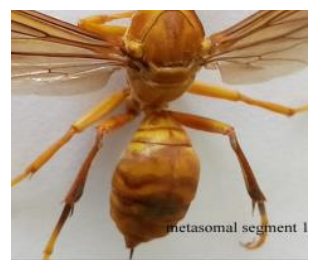

1) P.watti

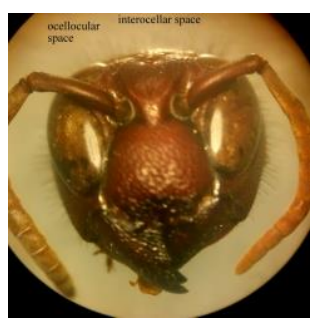

p') Head of Vespa

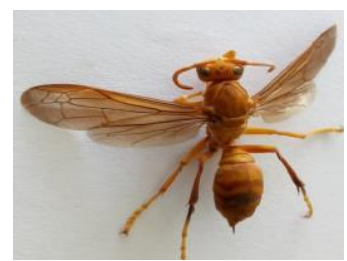

m') P.watti

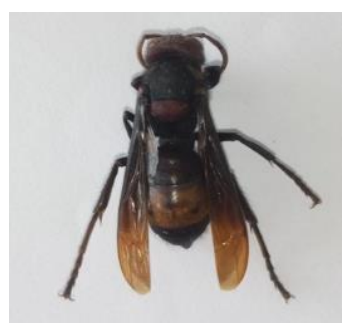

q') V.tropica

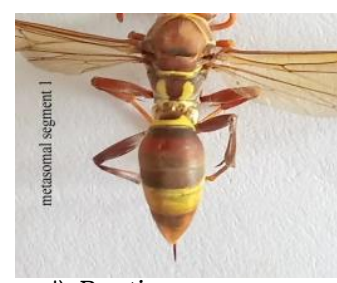

n') P. stigma

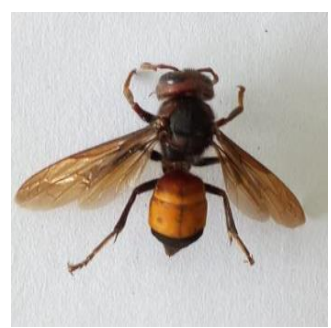

r') V. affinis

Fig.1. (a- r') Morphological characteristics of 14 collected species of Wasps

Bodlahet al. (2016) reported three species Polistes indicus, $P$. rothneyi and $P$. olivaceusof genus Polistesin Pakistan. Kumar and Sharma (2015) also reported 14 genera 33 species of wasps belonging from Chattisgarh.

A total 351 wasps were collected from three different study areas. It was investigated that among the different wasps the highest number was in $P$. olivaceus77 (21.93\%), and the lowest number was C. bengalense $3(0.86 \%)$ (Table-1). In the present study, it was observed that the presence of wasp population was high $(29.63 \%)$ in May and $(24.50 \%)$ in October. The wasps were found almost absent in January $(0.28 \%)$ and February $(0.28 \%)$ in all the study areas (Fig.3). After the mid-April, their population started to increase. Islam et al. (2015)investigated the seasonal abundance and efficiency of Vespa sp. They observed that the population of Vepa $s p$. increased gradually from August to October the highest number was in October. During the investigation, the maximum number of wasps (47.58\%) was collected from Curzon hall area and the minimum number (12.25\%) was collected from Ramna Park area (Table-1). According to Richter (2000), social wasps are not only visit flowers, they also imbibe plant sap from plants and sweet liquid from fruits. In the study, it was observed that the wasps were visiting more on the hedging plants than the flowering plants. All the 14 species wasps were collected from the hedging plants (Table-2).Social wasps include as bioindicators such as two wasp species in Europe (Kowalczyk and Watala 1989; Urbiniet al. 2006). The richness and 


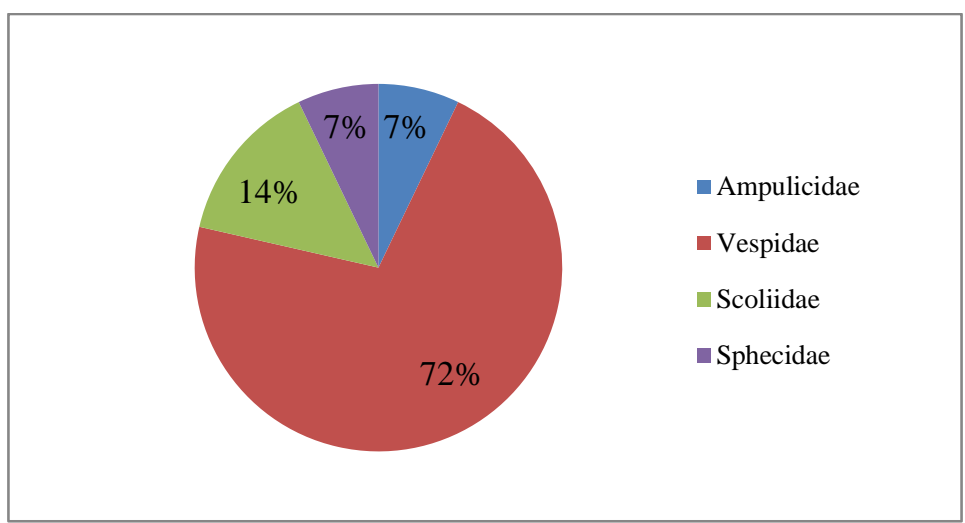

Fig. 2. Percentage of collected species under different family

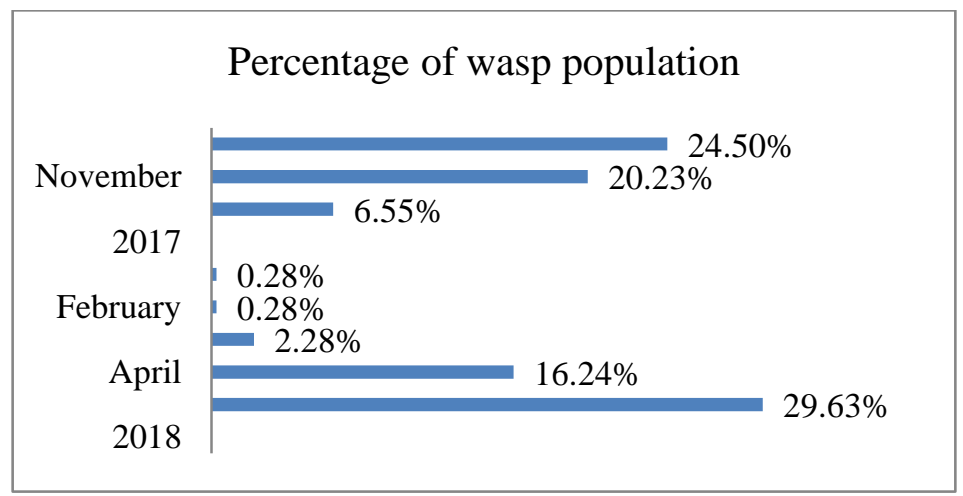

Fig.3. Percentage of total wasp population per month collected from October 2017 to May 2018

abundance of wasps give a tremendous data base to help in biodiversity conservation the pertinent part in terrestrial ecosystem provide a vast information base to assist in biodiversity conservation the relevant role in terrestrial ecosystems. Considering the importance of social wasps as pest of other insects and pollinator there is a lack of studies focusing on the applicability of this insect to highlight environmental quality in Dhaka city. Since they protect crops, make ecosystems thrive, sustain fruit and flowers therefore further study of wasps is essential to find out their role as bioindicator and in biodiversity conservation.

\section{LITERATURE CITED}

AKTER, T., AKHTER, S., SUlTANA, S., JHORNA, A. J. and BEGUM, S. 2019. The bees (Apocrita: Hymenoptera) of Dhaka city, Bangladesh. J. Biodivers. Conserv. Bioresour. Manag. 5(1): 113119. 
ALEXANDRE, P. A., ANDREW, R. D., MICHAEL, S., E., FORSHAGE, M., JOHN, T. H., JOHN, T. J., NORMAN, F. J., ARKADY, S. L., JOHN, T. L., LOHRMANN, V., MIKO, I., OHL, M., RASMUSSEN, C., TAEGER, A. and DICKY, S. K. Y. 2013. Order Hymenoptera. Zootaxa 3703 (1): 051-062.

AUGUL, R.S. 2016. Taxonomic study of the family Scoliidae (Hymenoptera; Aculeata) in Iraq J. Bio. Env. Sci. 8(2): 124-138.

BODLAH, I., ALI, H., AKRAM, M., NAEEM, M., MOHSIN, A. and AZIZ, M.A. 2016. First record of three species of genus Polistes (Vespidae: Hymemoptera) from district layyah (Punjab), Pakistan. Asian J. Agri. Biol. 4(2): 33-37.

BORROR, D.J., and DELONG, D.M. 1971. An introduction to the study of insects. 3rd edition. New York, USA, Holt, Rinehart \& Winston. pp. xiii +812 pp.

ISLAM, N., IFTIKHAR, F., and MAHMOOD, R. 2015. Seasonal variation in hornets spp. and efficiency of different traps as a tool for control. American J. Agricul. Sci. 2(6): 223-230.

JENNINGS, J. and AUSTIN, A. 1996. Native bees, wasps and ants: diversity and impact on other organisms. Environ. South. Australia 5(4):18.

KOWALCZYK, J.K. and WATALA, C. 1989. Content of some heavy metal ions in various developmental stages of the social wasp Dolichovespula saxonica (Fabr.) (Hymenoptera: Vespidae). Bull. Environ. Contamin \& Toxicol. 43(3):41-420.

KUMAR, P.G., and SHARMA, G. 2015. Taxonomic studies on vespid wasps (Hymenoptera: Vespoidea: Vespidae) of Chhattisgarh, India. J. Threaten. Taxa.7(14): 8096-8127.

GRIMALDI, D.A. and ENGEL, M.S. 2005. Evolution of the Insects. Cambridge University Press, New York. 755 pp.

GRZIMEK, B.D.G., KLEIMAN, V., GEIST, and McDADE, M.C. 2003. Grzimek's Animal Life Encyclopedia. $2^{\text {nd }}$ Edition, Volume 3.Thomson-Gale. 489pp.

GOULET, H. and HUBER, J.T. 1993. Hymenoptera of the world: An identification guide to families. Research Branch Agriculture Canada Publication, 680pp.

GOULET, H. and HUBER, J.T. 1993. Hymenoptera of the world: An identification guide to families. Research Branch Agriculture Canada Publication, 680pp.

GOULET, H. and HUBER, J.T. 1993. Hymenoptera of the world: An identification guide to families. Research Branch Agriculture Canada Publication, 680pp.

NAUMANN, I. D. 1991. Hymenoptera (Wasps, bees, ants, sawflies). In: The Insects of Australia. A text book for students and research workers. 2nd Edition. Melbourne University Press, pp. 916-1000.

NIDUP, T., KLEIN, W., KUMAR, P. G. and DORJI, P. 2017. New record of scoliid wasps (Hymenoptera: Scoliidae: Scoliinae) from Bhutan. Halteres 8: 9-19.

RASPlUS, J.Y., VILlEMANT, C., PAIVA, M.R., DELVARE, G., and ROQUES, A. 2010. Hymenoptera Chapter 12. Bio Risk 4(2): 669-776.

RICHTER, M.R. 2000. Social wasp (Hymenoptera: Vespidae) foraging behavior. Annu. Review Entomol. 45(1): 121-150.

STEFFAN-DEWENTER, I. 2003. Importance of habitat area and landscape context for species richness of bees and wasps in fragmented orchard meadows. Conserv. Boil. 17(4), 1036-1044.

URBNI, A., SPARVOLI, E. and TURILLAZI, S. 2006. Social paper wasps as bioindicators: a preliminary research with Polistesdominulus(Hymenoptera: Vespidae) as a trace metal accumulator. Chemosphere 64(5):697-703.

WENZEL, J.W. 1998. A generic key to the nests of hornets, yellow jackets, and paper wasps worldwide (Vespidae, Vespinae, Polistinae). American Museum novitates; No. 3224.

(Manuscript received on 12 August, 2019 revised on 10 February 2020) 